DOI: https://doi.org/10.31933/dijms.v2i3

Received: 30 July 2020, Revised: 25 August 2020, Publish: 23 January 2021

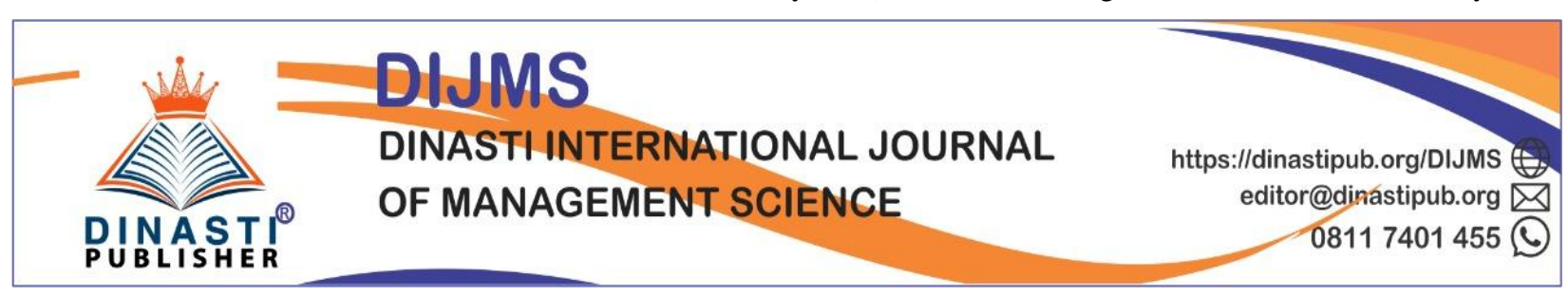

\title{
PURCHASE BEHAVIOR : ONLINE TOUR PACKAGE
}

\author{
Hamdan Hamdan ${ }^{1}$, Tine Yuliantini ${ }^{2}$ \\ 1) Universitas Mercu Buana, Jakarta, Indonesia, hamdan@mercubuana.ac.id \\ 2) Universitas Mercu Buana, Jakarta, Indonesia, tine.yuliantini@mercubuana.ac.id
}

\section{Corresponding Author: First Author}

\begin{abstract}
The purpose of this study was to analyze a model of online tour package purchasing behavior which is influenced by the perceptual aspects of review ratings, perceived risk, trust and purchase intention. The research design used a combination of exploratory, descriptivequantitative research. The population and sample selection uses consumers in West Jakarta who will purchase tour packages online. Determining the number of samples using purposive sampling technique and will be distributed to 203 consumers. These findings prove that the rating review positive effect on trust and perceptions of risk. Perceptions of risk have a negative effect on trust and purchase intention. Trust has a positive effect on purchase intention. This is an important consideration for business actors in making future marketing strategy decisions to achieve competitive advantage.
\end{abstract}

Keywords: trust, purchase intention, rating review, perceived risk.

\section{INTRODUCTION}

The digital economy revenue in Indonesia until the end of 2019 reached US \$ 40 billion. Of the total figures, the online travel sector contributed 10.2 percent of the revenue. Based on this data, the growth of online travel agents will be even more massive next year (Setiawan, 2019) and vice versa 84.6 percent of Indonesian tourists visit abroad (Rina Astini, 2020). The potential for online travel package business is a great opportunity to answer market needs, because (Yuliantini, 2019) tourist destinations are an important factor in influencing consumer intention in visiting. Rekarti \& Doktoralina, (2017) business actors need to make competitors as an act of orientation, so as not to lose competition in the future, namely (Woodruff, 1997) by creating consumer value is an important component to achieve competitive advantage, because Permana, (2017) with the right strategy can direct the effectiveness of strategic decision making in the future. One of the important factors that influence consumer value is psychological factors, where this factor is built by aspects of perception, learning, beliefs and attitudes (Kotler \& Keller, 2013).

In general there have been many previous studies examining e-commerce, showing that online purchasing behavior varies among different countries and socio-cultures (Ali, 2019; Haekal \& Widjajanta, 2016; Indrajaya \& Ali, 2017; Jalilvand et al., 2017; Zhao et al., 2019). Previous research has empirically proven that perceived value can influence online shopping behavior (Casaló et al., 2015; Chiu et al., 2014; Rekarti \& Hertina, 2014). The use of online pasckage purchasing sites can facilitate consumers in accessing various features of travel 
packages (Hamilton et al., 2016), as stated by (Kujur \& Singh, 2017), that posting relevant content will generate beneficial cognitive responses that lead to purchase decisions.

Quality information online travel packages, was instrumental in establishing trust online purchases than searching for information about the product (Ghasemaghaei \& Hassanein, 2015; Henny \& Dewi, 2017), for example when consumers buy products require physical inspection before buying, so it's necessary to examine the factors that mitigate the various risks in influencing online purchasing behavior (Aghekyan-Simonian et al., 2012). Consumer purchase intentions are reflected in actual purchasing behavior, where online vendors are required to understand the aspects that shape consumer behavior (Li \& Huang, 2009). Such as convenience (Harahap, 2018), comfort and safety (Rekarti \& Hertina, 2014) and perceived risk (Crespo et al., 2009; Driediger \& Bhatiasevi, 2019; Shahzad et al., 2015).

There have been many previous studies examining perceived risk as an urgent factor influencing online purchasing behavior (Bhatnagar \& Ghose, 2004; Bonnin, 2020; Driediger \& Bhatiasevi, 2019; Mohd Suki \& Mohd Suki, 2017; Panda \& Misra, 2014; Yang et al., 2016). Previous research suggests that consumer confidence is a strong factor in online purchases, while consumers trust in a product has the ability to mediate risk perceptions of purchase intention (Mortimer et al., 2016). To reduce perceived risk, online vendors can improve and manage the offered online tour package applications (Bonsón Ponte et al., 2015), such as the review rating feature, where the review can conclude how likely it is that consumers recommend to others and predict the future product in success (Chevalier \& Mayzlin, 2006; Y. Zhang et al., 2017). Review ratings help contribute better understand product features and reduce the risk of errors when purchasing products (Aghekyan-Simonian et al., 2012; Beck \& Crié, 2018).

Building reputation is a social process that depends on past interactions, especially the level of honesty that sellers showed in previous transactions (Han et al., 2018), such as online review ratings are defined as the user's rating of a product's preference for customer experience (Ichsan et al., 2018). An online store ranking scheme is to give stars, the more stars, the better seller ratings (Stouthuysen et al., 2018).

Online review ratings are a determinant of buying behavior and can also be used as an indicator of the reputation of a product or company that will influence the willingness to buy (Jana, 2015; Lackermair et al., 2013). Like the research developed (Heng et al., 2018; Ichsan et al., 2018; J. Park et al., 2019; Putra \& Riorini, 2016; Yang et al., 2016) prove that customer reviews on online stores can improve decisions purchase. Online review ratings can influence trust and increase sales (Frederick F.Reichheld, 2003; Tuk et al., 2009).

Previous findings suggest that positive online reviews can improve buying behavior ( $R$. Y. Kim, 2019; V. Wangenheim \& Bayón, 2007). The "thumbs up and comments" of online shopping websites allow consumers to express feelings about the information that has been posted (Barreda et al., 2015). Just as (Filieri, 2015) review ratings have a strong influence on consumer purchasing decisions, (Chen \& Xie, 2008) especially consumers who provide reviews indicate the level of perceived trust of the product.

The rapid growth of online travel packages makes business competition more stringent, especially in attracting consumers to order travel packages online. In order to be able to compete and attract as many consumers as possible, online travel agents must establish trust. Consumer confidence can be achieved, if consumers already feel safe and comfortable, especially with the results of a positive review rating can reduce the concern of consumers to decide on booking travel packages online. This will also cause purchase intention, because online travel agents have provided services in accordance with consumer expectations. 
This phenomenon encourages the need for research into consumer behavior that focuses on consumer perceptions that have the potential to influence trust and purchase intention. In addition, limited empirical evidence to determine factors that reduce perceived risk based on the results of review ratings will influence the buying behavior of online travel packages. The research model developed is how the online travel package purchasing behavior is built by the perception of review ratings and risk perceptions that affect on trust and purchase intention.

Thus, the formulation of the problem of this research are: a) how the ranking of reviews has a positive effect on trust; b) how the review rating positively influences risk perception; c) how trust has a positive influences purchase intention; d) how risk perception negatively influences trust; e) how risk perception negatively influences purchase intention; and f) how the role of trust plays in mediating risk perception with purchase intention.

This research is expected to contribute both practically and theoretically, namely: a) practical contributions. The behavior model of purchasing online tour packages is expected to provide benefits to online travel agents, to increase sales and excel in future competition; $b$ ) theoretical contribution. This research is expected the contribute for science to online travel package purchasing behavior and for further research it can develop research models regarding online tour package purchase behavior, especially the factors that reduce various risks in influencing purchase intention. In addition, the novelty of this research focuses on review ratings, because not all consumers have the same experience when traveling and are also influenced by the situation and condition of the tourist destination. This gives rise to very complex consumer perceptions, so the importance of developing research on online behavior models for purchasing tour packages.

\section{LITERATURE REVIEW Purchase Intention}

Intention is a matter relating to one's tendency to take an action or behave in a certain manner (Schiffman \& Kanuk, 2007). As for (Fishbein \& Ajzen, 1975) in the theory of reasoned action defines the intention to behave as an individual's tendency to do some behavior and (Ajzen, 1991) the formation of a certain behavior, because (Agrebi \& Jallais, 2015; L. Zhang et al., 2019) attitude positive user towards a system leads to the intention of favorable behavior towards the acceptance and continuation of technology.

Lack of intention to behave online shopping is a major barrier in online purchasing (Zhao et al., 2019), due to the perceived risk of reducing repurchase intentions (Gan \& Wang, 2017). Conversely, when consumers are satisfied with online purchases, it can increase the intention to behave online shopping (Agrebi \& Jallais, 2015; Driediger \& Bhatiasevi, 2019; Gan \& Wang, 2017; Sarkar et al., 2020; Tran et al., 2019).

Fishbein \& Ajzen (1975) uses 3 aspects in shaping purchase intention, namely: 1) consumer attitudes toward buying behavior; 2) subjective norms of buying behavior; and 3) behavioral control over buying behavior. Aspects of this research were adjusted by (Aghekyan-Simonian et al., 2012; Driediger \& Bhatiasevi, 2019; Shim et al., 2001; Yang et al., 2016) in the online shopping behavior studies model, including: (Crespo et al., 2009) possibility to buy, ability to buy, willingness to buy, reference to purchase, (Mortimer et al., 2016) hopes to buy back in the near future, and (Gan \& Wang, 2017) recommendations and purchase intention.

\section{Rating Review}


Consumer online rating is part of consumer online review, because consumer rating is a consumer review given or presented on a star-shaped scale (Lackermair et al., 2013). Ratings and reviews can reduce consumers' sense of uncertainty by providing a more concrete picture of a product or service being offered, because reviews are the main source of information for consumers (Chen \& Xie, 2008). Information obtained by consumers raises an opinion on a product, thus triggering consumer buying interest (Chevalier \& Mayzlin, 2006; Haekal \& Widjajanta, 2016; Y. Zhang et al., 2017).

To reduce the perceived risk to consumers, online vendors can enhance and manage online shopping applications (Heng et al., 2018; Ichsan et al., 2018; Jana, 2015; Lackermair et al., 2013; Yang et al., 2016), such as product review ranking features that enable consumers to recommend others (Tran et al., 2019). Building reputation is a process of past social interaction through online review ratings as a product preference for customer experience (E. M. Zhang, 2010). The research model developed by (Filieri, 2015) uses aspects that can increase the success of online vendors, including: overall product ratings, consumer review ratings, quality of information, source credibility, amount of information, diagnosis of information and suitability of information. Just as (D. H. Park et al., 2007) proves that review ratings can influence purchasing behavior through various aspects, such as: attitudes toward reviews, product quality reviews, product number reviews, positive activity reviews, product information, perception of information activities and perception of popularity product.

The research model developed by (Chen \& Xie, 2008; Flanagin \& Metzger, 2007; Frederick F.Reichheld, 2003; Tuk et al., 2009; Y. Zhang et al., 2017) found that review ratings can shape consumer confidence and (Heng et al., 2018; Ichsan et al., 2018; R. Y. Kim, 2019; J. Park et al., 2019; V. Wangenheim \& Bayón, 2007) increased online shopping purchases. Review ratings help consumers gain an understanding of product characteristics, thereby reducing the risk of mistakes when buying products (Beck \& Crié, 2018; Filieri, 2015; J. Kim \& Forsythe, 2009). Thus, based on a review of previous research studies which are the basis in building a research model, the hypotheses proposed are:

$\mathrm{H}-1$ : Rating review have a positive influence on trust.

H-2: Rating review have a positive influence on perceived risk.

\section{Trust}

Apart from risk perception, trust has also become an urget consideration factor towards online shopping behavior (Ha \& Janda, 2014; Matute et al., 2016; I. O. Pappas, 2018; Silva et al., 2019). Trust is also tight relationship to risk perception and previous research have modeled this construct together in online shopping behavior research (Ashman \& Vazquez, 2012; Becerra \& Korgaonkar, 2011; Glover \& Benbasat, 2010; Lai et al., 2013). Previous research developed by (Awad \& Ragowsky, 2008; Melorose et al., 2015) shows that trust in web content providers will be an important factor in the benefits of user perceived convenience. When consumers already have confidence in a product will increase the desire of consumers to make purchases on the product (J. Park et al., 2019; Sidharta et al., 2018).

The trust level can increase the positive attitude of consumers to providers that will affect interest in buying online (Awad \& Ragowsky, 2008; N. Pappas, 2016). Without strong trust in service providers, consumers will be reluctant to make purchasing decisions, on the other hand service providers can enable to increase consumer expectations to use the website safely (Melorose et al., 2015). Like the research developed by (Ahn et al., 2014) found a significant influence among trust with the intention to buy online. Lai et al. (2013) also found a positive effect of trust with consumers buying interest. While the findings (Astini, 2020) that the trust does not significantly influence the purchase decision. From the description of 
the review previous studies on consumer confidence in using online shopping sites, it has become an empirical basis in building a research model, the hypotheses proposed are:

H-3: Trust has a positive influence on purchase intention.

\section{Perceived Risk}

Risk performance's defined as the likelihood that a product will not perform as advertised, because it fails to deliver the expected benefits (Grewal et al., 1994). Perception of risk consists of several aspects including: psychological risk, social risk, performance risk, financial risk, time risk, privacy risk, and product risk (Pudaruth \& Nursing, 2017; AghekyanSimonian et al., 2012; Driediger \& Bhatiasevi, 2019; Nepomuceno et al., 2014; J. Kim \& Forsythe, 2009; Crespo et al., 2009; Adnan, 2014). The perceived risk plays an important role in increasing volatility in the online shopping environment (Li \& Huang, 2009; Sarkar et al., 2020), because perceived risk has a significant influnce on perceived benefits of online shopping (Driediger \& Bhatiasevi, 2019; Gan \& Wang, 2017; Octavia \& Tamerlane, 2017). Likewise (Mohd Suki \& Mohd Suki, 2017) that perceived risk has a negative effect on attitudes and (Nepomuceno et al., 2014) purchase intentions. In addition, perceived risk has an influence on consumer purchase interest which is mediated by trust (Sarkar et al., 2020; Aghekyan-Simonian et al., 2012).

Research (Adnan, 2014; Casaló et al., 2015; Chiu et al., 2014; Featherman \& Pavlou, 2003; Li \& Huang, 2009; Sarkar et al., 2020; Yoo \& Kim, 2012) suggest that risk perception influences negative to purchase intention, while (Gan \& Wang, 2017) stated that risk perception has no significant influence on purchase intention. As with (Mortimer et al., 2016; Rekarti \& Hertina, 2014), the perception of risk has a negative influence on trust. The research model (Chang \& Tseng, 2013; Chevalier \& Mayzlin, 2006; Huang, 2009; J. Park et al., 2019; Y. Zhang et al., 2017) found a mediating risk perception between trust and purchase intention. From the description of previous research reviews, it can be proposed that the research hypothesis is:

$\mathrm{H}-4$ : Perceived risk has a negative influence on trust.

H-5: Perceived risk has a negative influence on purchase intention.

\section{RESEARCH METHODS}

This study uses the design combination of a explanatory, descriptive, and quantitative research. Using explanatory research, because this study explains the relationship between variables. Exploratory research is the basis for more conclusive research in determining research designs and data collection techniques (Singh, 2007). The study population uses consumers who are in the West Jakarta area. Hair et al. (2010) in determining sample size, SEM assumptions must be met, ie processed samples are greater than 100 samples. Thus a minimum 203 study samples were determined. The selection of consumers as a sample uses purposive sampling technique, namely the deliberate selection of informants based on their ability to explain specific themes, concepts, or phenomena (Robinson, 2014). Criteria for informants is consumers who have never booked travel packages online.

This research data analysis technique uses Structural Equation Modeling-Covariance Linear Structural Relationship program. Hair et al. (2010) SEM with the Confirmatory Factor Analysis measurement model has an evaluation of the level of compatibility of the data with the model carried out several stages, namely: 1) overall model fit, namely evaluating the Good of Fit (GOF) between the data and the model; 2) measurement fit model, namely evaluation with the criteria for factor loading $\geq 0.50$ items are declared valid, Construct 
Reliability (CR) $\geq 0.70$ and Average Variance Extracted (AVE $\geq 0.50$ stated that items have reliability and diversity in explaining latent constructs; and 3) structural model fit, namely: evaluation of the structural model by testing the relationship between variables. Is the positive path coefficient or negative.

\section{FINDINGS AND DISCUSSION Findings}

This research is about the Online Tour Package Purchase Behavior Model. The data and information generated will be described based on the results of testing on the influence between variables to get an empirical model. The results of testing using SEM-Covarian are carried out through 3 evaluation processes, namely: overall model fit, measurement fit model, and structural model fit.

\section{Overall Model Fit}

The results of the fit test for the whole model, through the evaluation of the absolute fit measures, obtained a marginal fit, because the value of RMSEA $=0.094 \geq 0.08$ and the marginal fit for the value of GFI $=0.88 \leq 0.90$. For the results of the incremental fit measures, the value of $\mathrm{CFI}=$ $0.97 \geq 0.90$ is stated as good fit, NFI $=0.96 \geq 0.90$ is stated as good fit, and IFI $=0.97 \geq 0.90$ is stated as good fit. Meanwhile, the results of the parsimony fit measures obtained the value of AGFI $=0.78 \leq 0.90$, and PGFI $=0.47 \leq 0.50$ can be stated as marginal fit. The results of all models are still said to be good because they are at the level of good test criteria. Although some results of the fit of the overall model have not met the GOF criteria, including: RMSEA, GFI, AGFI and PGFI.

\section{Measurement Model Fit}

To determine the contribution of indicator items in explaining latent variables, the CFA measurement model is used. The results of the measurement model of this study are shown in Table 2 below.

Table 1. Measurement Model Results

\begin{tabular}{|c|c|c|c|c|}
\hline Latent Constructs & $\lambda$ & $\varepsilon$ & $\mathbf{C R}$ & AV \\
\hline $\begin{array}{l}\text { Review Rating: } \\
\text { Identification of travel packages } \\
\text { Rating reviews can be trusted } \\
\text { Rating reviews are based on facts }\end{array}$ & $\begin{array}{l}0.51 \\
0.68 \\
0.69\end{array}$ & $\begin{array}{l}0.74 \\
0.53 \\
0.53\end{array}$ & 0.662 & 0.399 \\
\hline $\begin{array}{l}\text { Risk Perception: } \\
\text { Worried of no benefit } \\
\text { Worried not on time } \\
\text { Worried not according to performance } \\
\text { Worried not to order } \\
\text { Worried the refund is not suitable } \\
\text { Worried not to match the price }\end{array}$ & $\begin{array}{l}0.53 \\
0.90 \\
0.87 \\
0.87 \\
0.91 \\
0.89 \\
\end{array}$ & $\begin{array}{l}0.73 \\
0.19 \\
0.24 \\
0.24 \\
0.16 \\
0.22 \\
\end{array}$ & 0.932 & 0.660 \\
\hline $\begin{array}{l}\text { Trust: } \\
\text { Sure on ratings review } \\
\text { Believe in review ratings } \\
\text { - Reviewers can be trusted }\end{array}$ & $\begin{array}{l}0.86 \\
0.84 \\
0.88 \\
\end{array}$ & $\begin{array}{l}0.27 \\
0.29 \\
0.23 \\
\end{array}$ & 0.893 & 0.737 \\
\hline $\begin{array}{l}\text { Purchase Interest: } \\
\text { The desire to buy } \\
\text { Willingness to buy } \\
\text { The possibility of continuing to buy }\end{array}$ & $\begin{array}{l}0.93 \\
0.99 \\
0.90\end{array}$ & $\begin{array}{l}0.13 \\
0.01 \\
0.18\end{array}$ & 0.961 & 0.892 \\
\hline
\end{tabular}

Source: Lisrel Data Process Results 
Based on the results of measurement model in selected indicators are valid indicators and have met the criteria at the test level both in measuring the latent variables, while the invalid indicators have been excluded from the research model. The results of the CR rating rating are below 0.70 and $\mathrm{AV}$ is below 0.50 , it can be stated that the review rating indicators do not meet the good or reliable and varied test criteria. While the risk perception CR value is above 0.70 and the AV value is above 0.50 , meaning that the risk perception indicators have met the test criteria well or can be said to be reliable and have diversity in measuring their latent variables.

The results of the CR value of confidence are above 0.70 and AV above 0.50 , meaning that it can be stated that the indicators used have met the good test criteria, because they have reliability and diversity in measuring latent variables. Likewise, the CR and AV values of purchase intention, have met the test criteria both, because the CR value is above 0.70 and the $\mathrm{AV}$ value is above 0.50 , meaning the items indicator used have reliability and diversity in describe of latent variables.

\section{Structural Model Fit}

The fit of the structural model is used to confirm the hypothesized relationships from the built model, by looking at the results of the path coefficients between variables. The estimation results of each exogenous latent variable against the endogenous latent variable using the Maximum Likelihood (ML) rule on the path coefficient results of the structural model are shown in Figure 1 below.

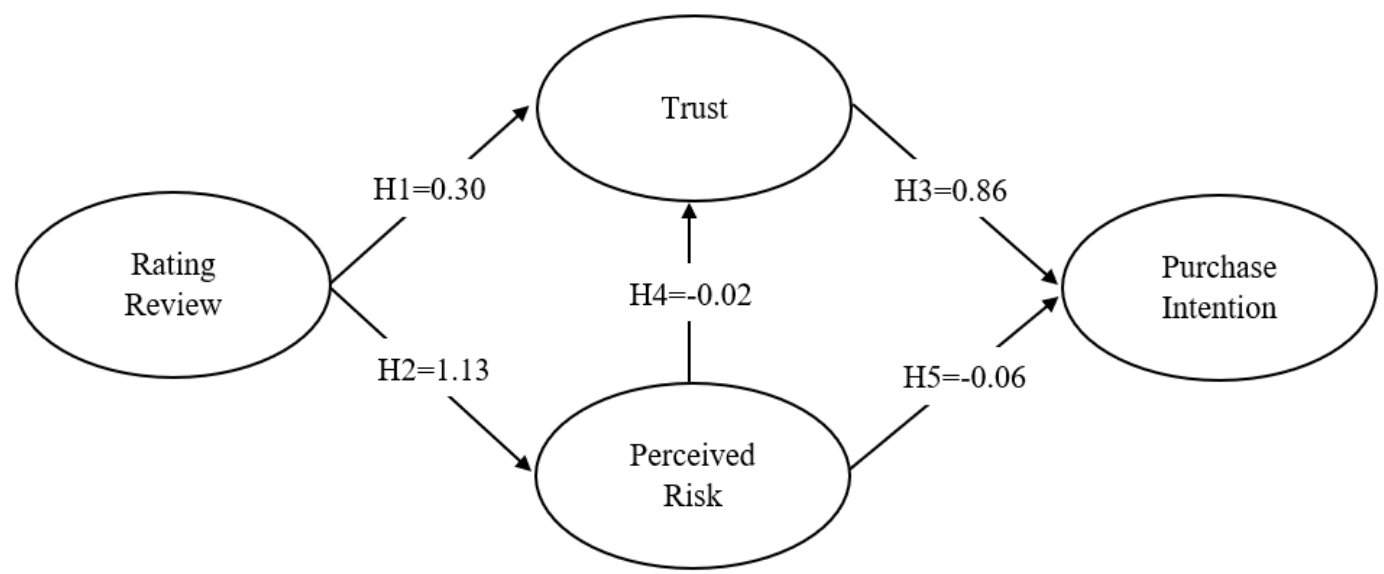

Figure 1. Structural Model Fit Results

\section{Discussion}

From the results of the structural model constructed, the path coefficient values obtained for all hypothesized relationships. The relationship between variables gives an understanding that online purchase intention is influenced by rating review factors, risk perception and trust.

Rating review have a positive influence on trust. The results of the structural model the first hypothesis (H1) show that the value of the path coefficient between the review rating and confidence is 0.30 . This means that a review rating has a positive influence on trust. Thus the first hypothesis can be accepted. Review ratings are the result of relevant information from various consumers who already have experience, this makes new consumers who are looking for information about an online tour package tend to believe when buying it. This is revealed by (Chen \& Xie, 2008; Flanagin \& Metzger, 2007; Reichheld, 2003; Tuk et al., 2009; Zhang et al., 2017) that review ratings can build consumer confidence in online shopping behavior. 
Rating review have a positive influnce on risk perception. The structural model results the second hypothesis $(\mathrm{H} 2)$ show that the value of the path coefficient between review ratings and risk perception is 1.13. This means that review ratings have a positive effect on risk perceptions, thus the second hypothesis can be accepted. When the review rating is as expected in seeking information, it will reduce the negative impact on the interest in buying online travel packages. This is confirmed by (Ichsan et al., 2018; Lackermair et al., 2013; Tran et al., 2019; Beck \& Crié, 2018; Filieri, 2015; Kim \& Forsythe, 2009) that ratings and reviews can reduce a sense of uncertainty consumer

Trust has a positive influence on purchase intention. The structural model the third hypothesis (H3) indicate that the path coefficient value between trust and purchase intention is 0.86. This means that trust has a positive effect on purchase intention, thus the third hypothesis can be accepted. The higher consumer confidence in online travel packages, the more positive attitudes of consumers towards the desire to buy. The results of this study are consistent (Amaral et al., 2013; Ha \& Janda, 2014; Kim et al., 2008; Sidharta et al., 2018; Lee, 2011; Awad \& Ragowsky, 2008; Pappas, 2018; Melorose et al. , 2015; Ahn et al., 2014) state that a high level of trust can increase consumers' positive attitudes towards service providers which will affect the interest in buying online.

Risk perception has a negative influencet on trust. The structural model results in the fourth hypothesis $(\mathrm{H} 4)$ show that the path coefficient between risk perception and trust is 0.02. That is, the perception of the risk of a negative influence on trust, thus the fourth hypothesis can be accepted. The reduced risk felt by consumers, the more consumer confidence in online tour packages will increase. These findings are consistent with (Mortimer et al., 2016; Rekarti \& Hertina, 2014; Chang \& Tseng, 2013; Chevalier \& Mayzlin, 2006; Li \& Huang, 2009; J. Park et al., 2019; Y. Zhang et al., 2017) states that risk perception negatively affects trust.

Risk perception has a negative influence on purchase intention. The structural model results in the fifth hypothesis (H5) show that the path coefficient between risk perception and purchase intention is -0.06 . That is, the perception of the risk of a negative influence on purchase intentions, thus the fifth hypothesis can be accepted. The reduced perceived risk, it will lead to consumer buying interest in online travel packages. The results of this study are in accordance with (Adnan, 2014; Casaló et al., 2015; Chiu et al., 2014; Featherman \& Pavlou, 2003; Li \& Huang, 2009; Sarkar et al., 2020; Yoo \& Kim , 2012) states that risk perception negatively affects purchase intention.

\section{CONCLUSION AND RECOMENDATION Conclusion}

The results of the study are answers to the objectives of the research that was built, namely the behavior of purchasing online travel packages. The results of the research that were built, namely: 1) the ranking of reviews has a positive effect on questions, this shows that when consumers know the rating of reviews is true about the online travel packages offered will form a positive attitude and trust when using the online travel package application; 2) review ratings have a positive effect on risk perception, meaning that review ratings are important in reducing consumer uncertainty in using online travel package applications; 3) trust has a positive effect on purchase intention, meaning that when consumers believe in online travel package applications offered based on the ranking results and reviews received based on experience will lead to online purchase intention; 4) risk perception has a negative effect on trust, meaning that consumers will believe in deciding to use online travel packages, because knowing the perceived risk is in accordance with the offered tour packages; and 5) risk perception has a negative effect on online purchase 
intention, meaning that the perceived risk of consumers is comparable to the offered online tour packages, because on the basis of correct information and consumers knowing the consequences received will lead to interest in buying online travel packages.

\section{Recomendation}

Research on online tour package purchasing behavior has managerial implications for business actors to be superior in competition, in order to sustain business in the future. Suggestions that need to be considered are to implement the aspects built in this study, because they are an important aspect for the sustainability of a travel business or company that offers tour package services online in the future. These aspects namley: identifying tour packages that suit consumer needs, providing reliable reviews, providing fact-based reviews, offering tour packages according to benefits, providing appropriate travel time estimates, providing tour packages according to performance, providing appropriate travel destinations. with the order, provide a refund and an appropriate price. With these aspects will build the attitude of willingness and trust of consumers to make purchases and the possibility of continuing to buy.

The limitation of this study is still limited samples of data collection and population purchasing online travel packages, due to decreased purchasing power to travel both domestically and internationally. This is due to the current pandemic conditions. The researcher also recommends the factors that are lacking in this study to be studied further in further research, such as: safety factors, perceived utility, hedonic perception, service, store image, review ratings and trustworthiness.

\section{REFERENCE}

Adnan, H. (2014). An Analysis of the Factors Affecting Online Purchasing Behavior of Pakistani Consumers. International Journal of Marketing Studies, 6(5), 133-148. https://doi.org/10.5539/ijms.v6n5p133

Aghekyan-Simonian, M., Forsythe, S., Suk Kwon, W., \& Chattaraman, V. (2012). The role of product brand image and online store image on perceived risks and online purchase intentions for apparel. Journal of Retailing and Consumer Services, 19(3), 325331. https://doi.org/10.1016/j.jretconser.2012.03.006

Agrebi, S., \& Jallais, J. (2015). Explain the intention to use smartphones for mobile shopping. Journal of Retailing and Consumer Services, 22, 16-23. https://doi.org/10.1016/j.jretconser.2014.09.003

Ahn, T., Ik Suh, Y., Lee, J. K., \& Pedersen, P. M. (2014). Understanding purchasing intentions in secondary sports ticket websites. International Journal of Sports Marketing and Sponsorship, 16(1), 35-49. https://doi.org/10.1108/IJSMS-16-012014-B004

Ali, H. (2019). Building Repurchase Intention and Purchase Decision: Brand Awareness and Brand Loyalty Analysis (Case Study Private Label Product in Alfamidi Tangerang). Saudi Journal of Humanities and Social Sciences, 04(09), 623-634. https://doi.org/10.36348/sjhss.2019.v04i09.009

Ashman, R., \& Vazquez, D. (2012). Simulating attachment to pure-play fashion retailers. International Journal of Retail and Distribution Management, 40(12), 975-996. https://doi.org/10.1108/09590551211274955

Astini, R. (2020). Mediation of Need for Touch on Factors that Affecting on Online Purchasing Decisions. https://doi.org/10.4108/eai.26-11-2019.2295162

Astini, R. (2020). Identification of Internal Factors of Indonesia Tourists that Influence the Decision to Travel Shopping to Singapore. 120(Icmeb 2019), 311-319. https://doi.org/10.2991/aebmr.k.200205.053 
Awad, N. F., \& Ragowsky, A. (2008). Establishing trust in electronic commerce through online word of mouth: An examination across genders. Journal of Management Information Systems, 24(4), 101-121. https://doi.org/10.2753/MIS07421222240404

Barreda, A. A., Bilgihan, A., \& Kageyama, Y. (2015). The Role of Trust in Creating Positive Word of Mouth and Behavioral Intentions: The Case of Online Social Networks. Journal of Relationship Marketing, 14(1), 16-36. https://doi.org/10.1080/15332667.2015.1006002

Becerra, E. P., \& Korgaonkar, P. K. (2011). Effects of trust beliefs on consumers' online intentions. European Journal of Marketing, 45(6), 936-962. https://doi.org/10.1108/03090561111119921

Beck, M., \& Crié, D. (2018). I virtually try it ... I want it! Virtual Fitting Room: A tool to increase on-line and off-line exploratory behavior, patronage and purchase intentions. Journal of Retailing and Consumer Services, 40(December 2015), 279286. https://doi.org/10.1016/j.jretconser.2016.08.006

Bhatnagar, A., \& Ghose, S. (2004). Segmenting consumers based on the benefits and risks of Internet shopping. Journal of Business Research, 57(12 SPEC.ISS.), 1352-1360. https://doi.org/10.1016/S0148-2963(03)00067-5

Bonnin, G. (2020). The roles of perceived risk, attractiveness of the online store and familiarity with $\mathrm{AR}$ in the influence of $\mathrm{AR}$ on patronage intention. Journal of Retailing and Consumer Services, 52(May 2019), 101938. https://doi.org/10.1016/j.jretconser.2019.101938

Bonsón Ponte, E., Carvajal-Trujillo, E., \& Escobar-Rodríguez, T. (2015). Influence of trust and perceived value on the intention to purchase travel online: Integrating the effects of assurance on trust antecedents. Tourism Management, 47, 286-302. https://doi.org/10.1016/j.tourman.2014.10.009

Casaló, L. V., Flavián, C., Guinalíu, M., \& Ekinci, Y. (2015). Do online hotel rating schemes influence booking behaviors? International Journal of Hospitality Management, 49, 28-36. https://doi.org/10.1016/j.ijhm.2015.05.005

Chang, E. C., \& Tseng, Y. F. (2013). Research note: E-store image, perceived value and perceived risk. Journal of Business Research, 66(7), 864-870. https://doi.org/10.1016/j.jbusres.2011.06.012

Chen, Y., \& Xie, J. (2008). Online consumer review: Word-of-mouth as a new element of marketing communication mix. Management Science, 54(3), 477-491. https://doi.org/10.1287/mnsc. 1070.0810

Chevalier, J. A., \& Mayzlin, D. (2006). Chevalier2006. Journal of Marketing Research, XLIII(August), 345-354.

Chiu, C. M., Wang, E. T. G., Fang, Y. H., \& Huang, H. Y. (2014). Understanding customers' repeat purchase intentions in B2C e-commerce: The roles of utilitarian value, hedonic value and perceived risk. Information Systems Journal, 24(1), 85-114. https://doi.org/10.1111/j.1365-2575.2012.00407.x

Crespo, Á. H., Del Bosque, I. R., \& De Los Salmones Sanchez, M. M. G. (2009). The influence of perceived risk on Internet shopping behavior: A multidimensional perspective. Journal of Risk Research, 12(2), 259-277. https://doi.org/10.1080/13669870802497744

Driediger, F., \& Bhatiasevi, V. (2019). Online grocery shopping in Thailand: Consumer acceptance and usage behavior. Journal of Retailing and Consumer Services, 48(March 2018), 224-237. https://doi.org/10.1016/j.jretconser.2019.02.005

Featherman, M. S., \& Pavlou, P. A. (2003). Predicting e-services adoption: A perceived risk facets perspective. International Journal of Human Computer Studies, 59(4), 451474. https://doi.org/10.1016/S1071-5819(03)00111-3 
Filieri, R. (2015). What makes online reviews helpful? A diagnosticity-adoption framework to explain informational and normative influences in e-WOM. Journal of Business Research, 68(6), 1261-1270. https://doi.org/10.1016/j.jbusres.2014.11.006

Flanagin, A. J., \& Metzger, M. J. (2007). The role of site features, user attributes, and information verification behaviors on the perceived credibility of web-based information. New Media and Society, 9(2), 319-342. https://doi.org/10.1177/1461444807075015

Frederick F.Reichheld. (2003). The One Number You Need to grow. Harvard Business Review, Decembre 2003, 9. http://www.netzkobold.com/uploads/pdfs/the_one_number_you_need_to_grow_rei chheld.pdf\%5Cnhttp://hbr.org/product/one-number-you-need-to-grow/an/R0312CPDF-ENG

Gan, C., \& Wang, W. (2017). The influence of perceived value on purchase intention in social commerce context. Internet Research, 27(4), 772-785. https://doi.org/10.1108/IntR-06-2016-0164

Ghasemaghaei, M., \& Hassanein, K. (2015). Online information quality and consumer satisfaction: The moderating roles of contextual factors - A meta-analysis. Information and Management, 52(8), 965-981. https://doi.org/10.1016/j.im.2015.07.001

Glover, S., \& Benbasat, I. (2010). A comprehensive model of perceived risk of E-commerce transactions. International Journal of Electronic Commerce, 15(2), 47-78. https://doi.org/10.2753/JEC1086-4415150202

Grewal, D., Gotlieb, J., \& Marmorstein, H. (1994). The Moderating Effects of Message Framing and Source Credibility on the Price-Perceived Risk Relationship. Journal of Consumer Research, 21(1), 145. https://doi.org/10.1086/209388

Ha, H. Y., \& Janda, S. (2014). The effect of customized information on online purchase intentions. Internet Research, 24(4), 496-519. https://doi.org/10.1108/IntR-062013-0107

Haekal, A., \& Widjajanta, B. (2016). Minat Membeli Secara Online pada Pengunjung Website. Journal of Business Management and Education, 1(1), 181-193. http://ejournal.upi.edu/index.php/JBME/article/view/2287/1586

Hamilton, M., Kaltcheva, V. D., \& Rohm, A. J. (2016). Social Media and Value Creation: The Role of Interaction Satisfaction and Interaction Immersion. Journal of Interactive Marketing, 36, 121-133. https://doi.org/10.1016/j.intmar.2016.07.001

Han, B., Kim, M., \& Lee, J. (2018). Exploring consumer attitudes and purchasing intentions of cross-border online shopping in Korea. Journal of Korea Trade, 22(2), 86-104. https://doi.org/10.1108/JKT-10-2017-0093

Hair, J. F., Black, W. C., Babin, B. J., \& Anderson, R. E. (2010), Multivariate Data Analysis: A Global Perspective. 7the edn. Englewood Cliffs, NJ: Prentice-Hall.

Harahap, D. A. (2018). Perilaku Belanja Online Di Indonesia: Studi Kasus. JRMSI - Jurnal Riset Manajemen Sains Indonesia, 9(2), 193-213. https://doi.org/10.21009/jrmsi.009.2.02

Heng, Y., Gao, Z., Jiang, Y., \& Chen, X. (2018). Exploring hidden factors behind online food shopping from Amazon reviews: A topic mining approach. Journal of Retailing and Consumer Services, 42(January), 161-168. https://doi.org/10.1016/j.jretconser.2018.02.006

Henny, M., \& Dewi, U. (2017). Keputusan Pembelian Produk 'Online Travel Agent .' 4, 117.

Huang, Y.-K. (2009). The Effect of Airline Service Quality on Passengers' Behavioural Intentions Using SERVQUAL Scores: A TAIWAN Case Study. Journal of the Eastern Asia Society for Transportation Studies, 8(1), 2330-2343. 
https://pdfs.semanticscholar.org/cede/5829392008ed89cfc182ae47091e6ea6c131.p df

Ichsan, M., Jumhur, H. M., \& Dharmoputra, I. S. (2018). Pengaruh Consumer Online Rating and Review Terhadap Minat Beli Konsumen Pada Marketplace Tokopedia Di Wilayah Dki Jakarta. E-Proceeding of Management, 5(2), 1828-1835.

Indrajaya, H. S., \& Ali, H. (2017). Shopping Analysis in on Line Shop with Young People. The International Journal of Social Sciences and Humanities Invention, 4(7), 37973802. https://doi.org/10.18535/ijsshi/v4i8.17

Jalilvand, M. R., Nasrolahi Vosta, L., Kazemi Mahyari, H., \& Khazaei Pool, J. (2017). Social responsibility influence on customer trust in hotels: mediating effects of reputation and word-of-mouth. Tourism Review, 72(1), 1-14. https://doi.org/10.1108/TR-092016-0037

Jana, V. (2015). Online consumer reviews The case of misleading or fake reviews. European Parliamentary Research Service, October.

Kim, J., \& Forsythe, S. (2009). Adoption of sensory enabling technology for online apparel shopping. European Journal of Marketing, 43(9), 1101-1120. https://doi.org/10.1108/03090560910976384

Kim, R. Y. (2019). Does national culture explain consumers' reliance on online reviews? Cross-cultural variations in the effect of online review ratings on consumer choice. Electronic Commerce Research and Applications, 37(June), 100878. https://doi.org/10.1016/j.elerap.2019.100878

Kujur, F., \& Singh, S. (2017). Engaging customers through online participation in social networking sites. Asia Pacific Management Review, 22(1), 16-24. https://doi.org/10.1016/j.apmrv.2016.10.006

Lackermair, G., Kailer, D., \& Kanmaz, K. (2013). Importance of Online Product Reviews from a Consumer's Perspective. Advances in Economics and Business, 1(1), 1-5. https://doi.org/10.13189/AEB.2013.010101

Lai, Y. H., Huang, H. C., Lu, R. S., \& Chang, C. M. (2013). The effects of website trust, perceived ease of use, and perceived usefulness on consumers' online booking intention: Evidence from Taiwan B\&B sector. Life Science Journal, 10(2), 15161523.

Li, Y.-H., \& Huang, J.-W. (2009). Applying Theory of Perceived Risk and Technology Acceptance Model in the Online Shopping Channel. World Academy of Science, Engineering and Technology, 53(1), 919-925. http://citeseerx.ist.psu.edu/viewdoc/download?doi=10.1.1.193.6343\&rep=rep1\&typ $\mathrm{e}=\mathrm{pdf}$

Matute, J., Polo-Redondo, Y., \& Utrillas, A. (2016). The influence of EWOM characteristics on online repurchase intention. Online Information Review, 40(7), 1090-1110. https://doi.org/10.1108/oir-11-2015-0373

Melorose, J., Perroy, R., \& Careas, S. (2015). TRUST AND TAM IN ONLINE SHOPPING: AN INTEGRATED MODEL1 By: Statewide Agricultural Land Use Baseline 2015, 1(1), 51-90. https://doi.org/10.1017/CBO9781107415324.004

Mohd Suki, N., \& Mohd Suki, N. (2017). Modeling the determinants of consumers' attitudes toward online group buying: Do risks and trusts matters? Journal of Retailing and Consumer Services, 36(February), 180-188. https://doi.org/10.1016/j.jretconser.2017.02.002

Mortimer, G., Fazal e Hasan, S., Andrews, L., \& Martin, J. (2016). Online grocery shopping: the impact of shopping frequency on perceived risk. International Review of Retail, Distribution and Consumer Research, 26(2), 202-223. https://doi.org/10.1080/09593969.2015.1130737

Nepomuceno, M. V., Laroche, M., \& Richard, M. O. (2014). How to reduce perceived risk 
when buying online: The interactions between intangibility, product knowledge, brand familiarity, privacy and security concerns. Journal of Retailing and Consumer Services, 21(4), 619-629. https://doi.org/10.1016/j.jretconser.2013.11.006

Octavia, D., \& Tamerlane, A. (2017). The Influence of Website Quality on Online Purchase Intentions on Agoda.Com with E-Trust as a Mediator. Binus Business Review, 8(1), 9. https://doi.org/10.21512/bbr.v8i1.1680

Panda, R. K., \& Misra, S. (2014). Impact of Country-of-origin Image on Brand Equity: A Study on Durable Products in India. Procedia - Social and Behavioral Sciences, 150, 494-499. https://doi.org/10.1016/j.sbspro.2014.09.062

Pappas, I. O. (2018). User experience in personalized online shopping: a fuzzy-set analysis. European Journal of Marketing, 52(7-8), 1679-1703. https://doi.org/10.1108/EJM10-2017-0707

Pappas, N. (2016). Marketing strategies, perceived risks, and consumer trust in online buying behaviour. Journal of Retailing and Consumer Services, 29, 92-103. https://doi.org/10.1016/j.jretconser.2015.11.007

Park, D. H., Lee, J., \& Han, I. (2007). The effect of on-line consumer reviews on consumer purchasing intention: The moderating role of involvement. International Journal of Electronic Commerce, 11(4), 125-148. https://doi.org/10.2753/JEC10864415110405

Park, J., Amendah, E., Lee, Y., \& Hyun, H. (2019). M-payment service: Interplay of perceived risk, benefit, and trust in service adoption. Human Factors and Ergonomics In Manufacturing, 29(1), 31-43. https://doi.org/10.1002/hfm.20750

Permana, D. (2017). Toward the best model of strategy implementation in Indonesian Islamic banking from the lens of strategic clarity. European Research Studies Journal, 20(4), 3-15. https://doi.org/10.35808/ersj/870.

Pudaruth, S., \& Nursing, R. K. (2017). Exploring the Determining Factors Influencing Online Purchase Behaviour Among Consumers in Emerging Economies: a Case of Mauritius. International Journal of Arts \& Science, 10(01), 1-22.

Putra, S. A. W., \& Riorini, S. V. (2016). Pengaruh Online Reviews Terhadap Online Hotel Booking Intentions Pada Online Travel Agent Lokal. Prosiding Seminar Nasional Cendekiawan, $O(0)$,

27-1-27.11.

http://www.trijurnal.lemlit.trisakti.ac.id/index.php/semnas/article/view/911

Rekarti, E., \& Doktoralina, C. M. (2017). Improving Business Performance: A Proposed Model for SMEs. European Research Studies Journal, 20(3), 613-623. https://doi.org/10.35808/ersj/732

Rekarti, E., \& Hertina, L. (2014). Beberapa faktor yang berpengaruh terhadap minat beli online pada situs jual beli tokobagus.com. Jurnal Ilmu Ekonomi Dan Sosial, 2(3), 311-318.

http://digilib.mercubuana.ac.id/manager/t!@file_artikel_abstrak/Isi_Artikel_20911 3044032.pdf

Robinson, O. C. (2014). Sampling in Interview-Based Qualitative Research: A Theoretical and Practical Guide. Qualitative Research in Psychology, 11(1), 25-41. https://doi.org/10.1080/14780887.2013.801543

Sarkar, S., Chauhan, S., \& Khare, A. (2020). A meta-analysis of antecedents and consequences of trust in mobile commerce. International Journal of Information Management, 50(August 2019), 286-301. https://doi.org/10.1016/j.ijinfomgt.2019.08.008

Shahzad, F., Khattak, J. K., Khattak, M. J., \& Shahzad, F. (2015). Impact of consumer socialization on soft drink consumption and mediating role of consumer generational behavior. British Food Journal, 117(3), 1205-1222. 
https://doi.org/10.1108/BFJ-08-2013-0219

Shim, S., Eastlick, M. A., Lotz, S. L., \& Warrington, P. (2001). An online prepurchase intentions model. Journal of Retailing, 77(3), 397-416. https://doi.org/10.1016/s0022-4359(01)00051-3

Sidharta, R. B. F. I., Sari, N. L. A., \& Suwandha, W. (2018). Purchase Intention Pada Produk Bank Syariah Ditinjau Dari Brand Awareness Dan Brand Image Dengan Trust Sebagai Variabel Mediasi. Mix: Jurnal Ilmiah Manajemen, 8(3), 562. https://doi.org/10.22441/mix.2018.v8i3.007

Singh, K. (2007). Quantitative Social Research Methods. California: Sage Publications. https://research-methodology.net/research-methodology/researchdesign/exploratory-research/\#_ftnref2

Silva, J., Pinho, J. C., Soares, A., \& Sá, E. (2019). Antecedents of online purchase intention and behaviour: Uncovering unobserved heterogeneity. Journal of Business Economics and Management, 20(1), 131-148. https://doi.org/10.3846/jbem.2019.7060

Stouthuysen, K., Teunis, I., Reusen, E., \& Slabbinck, H. (2018). Initial trust and intentions to buy: The effect of vendor-specific guarantees, customer reviews and the role of online shopping experience放. Electronic Commerce Research and Applications, 27, 23-38. https://doi.org/10.1016/j.elerap.2017.11.002

Tran, L. T. T., Pham, L. M. T., \& Le, L. T. (2019). E-satisfaction and continuance intention: The moderator role of online ratings. International Journal of Hospitality Management, 77(November 2017), 311-322. https://doi.org/10.1016/j.ijhm.2018.07.011

Tuk, M. A., Verlegh, P. W. J., Smidts, A., \& Wigboldus, D. H. J. (2009). Sales and sincerity: The role of relational framing in word-of-mouth marketing. Journal of Consumer Psychology, 19(1), 38-47. https://doi.org/10.1016/j.jcps.2008.12.007

V. Wangenheim, F., \& Bayón, T. (2007). The chain from customer satisfaction via word-ofmouth referrals to new customer acquisition. Journal of the Academy of Marketing Science, 35(2), 233-249. https://doi.org/10.1007/s11747-007-0037-1

Yang, J., Sarathy, R., \& Lee, J. K. (2016). The effect of product review balance and volume on online Shoppers' risk perception and purchase intention. Decision Support Systems, 89, 66-76. https://doi.org/10.1016/j.dss.2016.06.009

Yoo, J.-J., \& Kim, H.-Y. (2012). Perceived Risk of Sunless Tanning Product Use and Its Relationship to Body Satisfaction. International Journal of Marketing Studies, 4(4), 13-21. https://doi.org/10.5539/ijms.v4n4p13

Yuliantini, T. (2019). Analysis of Destination Image, Tourism Object, and Infrastructure Effect on Tourism Visiting Intention to Wamena (A Case Study of Tourism Development Planning in Wamena). Journal of Marketing and Consumer Research, 59(2018), 37-46. https://doi.org/10.7176/jmcr/59-06

Zhang, E. M. (2010). Understanding the Acceptance of Mobile SMS Advertising among Young Chinese Consumers. Psychology \& Marketing, 30(6), 461-469. https://doi.org/10.1002/mar

Zhang, L., Wang, S. F., Lin, Z. Z., \& Wu, Y. (2019). Online ballot stuffing: Influence of selfboosting manipulation on rating dynamics in online rating systems. Telematics and Informatics, 38(November 2018), 1-12. https://doi.org/10.1016/j.tele.2019.01.009

Zhang, Y., Trusov, M., Stephen, A. T., \& Jamal, Z. (2017). Online shopping and social media: Friends or foes? Journal of Marketing, 81(6), 24-41. https://doi.org/10.1509/jm.14.0344

Zhao, J. Di, Huang, J. S., \& Su, S. (2019). The effects of trust on consumers' continuous purchase intentions in $\mathrm{C} 2 \mathrm{C}$ social commerce: A trust transfer perspective. Journal of Retailing and Consumer Services, 50(January), 42-49. 
https://doi.org/10.1016/j.jretconser.2019.04.014

\section{Thank-you Note}

Hamdan has obtained his Bachelor's (2015), and Master (2017) degrees in Mercu Buana University Jakarta-Indonesia in the Faculty of Economics and Business. He has been a lecturer since September 2017 at the Mercu Buana University. Focus of his research is on online shopping behavior intentions. Researcher would like to express their deepest gratitude to the University of Mercu Buana Research Center for funding this research. 